
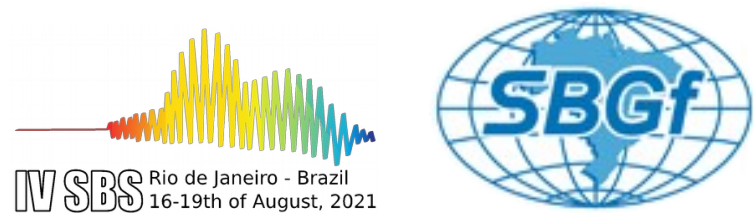

\title{
Neotectônica e Sismicidade na Borda Sudeste da Bacia do Pantanal Sul Mato- Grossense
}

\author{
Edna Facincani, UFMS/FAENG, Estevão Tadeu, UFMS/FAENG \\ Copyright 2021, SBGf - Sociedade Brasileira de Geofísica. \\ This paper was prepared for presentation during the $17^{\text {th }}$ International Congress of the Brazilian Geophysical Society held in Rio de Janeiro, Brazil, 16-19 August 2021. \\ Contents of this paper were reviewed by the Technical Committee of the $17^{\text {th }}$ International Congress of the Brazilian Geophysical Society and do not necessarily represent any position of \\ the SBGf, its officers or members. Electronic reproduction or storage of any part of this paper for commercial purposes without the written consent of the Brazilian Geophysical Society is \\ prohibited.
}

\section{Resumo.}

A expressão maior da Neotectônica no Estado de Mato Grosso do Sul é representada pela Bacia Sedimentar do Pantanal, considerada uma fossa tectônica de direção N-S, com $400 \mathrm{~km}$ de comprimento e $250 \mathrm{~km}$ de largura e espessura acima de $400 \mathrm{~m}$ de sedimentos. O Pantanal localiza-se no Oeste do Estado de Mato Grosso do Sul, ocupando uma área de $135.000 \mathrm{~km}^{2}$. A planície pantaneira é circundada pelos planaltos de MaracajuCampo Grande e Taquari-Itiquira a leste, Guimarães e Parecis a Norte, Urucum-Amolar a oeste e Bodoquena a Sul. A região é envolvida por planaltos sustentados por rochas que variam de idades desde o Pré-Cambriano até o Cenozóico. Historicamente a Bacia Sedimentar do Pantanal é considerada uma das regiões sísmicas do Brasil. Os abalos sísmicos intraplaca resultam de rupturas ao longo de zonas de fraquezas preexistentes, localizadas próximas de inomogeneidades estruturais, as quais concentram esforços que, somados aos esforços regionais, são capazes de gerar terremotos. As principais feições estruturais identificadas tratam-se de descontinuidades, marcadas por juntas e falhas. Foram reconhecidas dois conjuntos de falhas dos tipos: normal e transcorrente. As falhas normais são àquelas representadas na abertura da bacia de direção NE-SW, enquanto às transcorrentes são mais jovens e caracterizadas por descontinuidades de direção E-W. O binário de direção E-W e com movimentação dextral, possibilita o desenvolvimento de descontinuidade de direção NW$\mathrm{SE}$. A rede de drenagem e a estrutura das formas de relevo apresentam-se fortemente controladas por essas descontinuidades estruturais, associadas à abatimento de blocos presentes na região. Isto possibilita o desenvolvimento de áreas com maior subsidência e espaço de acomodação de sedimentos holocênicos na bacia, como o chamado "Brejão do Negro", que revelou ser uma área frequentemente inundada, marcada por um lago fluvial oculto em função de um tapete flutuante de macrófitas. O lineamento do Rio Negro é uma feição sismo-tectônica importante na porção sudeste da Bacia do Pantanal, funcionando como uma zona de cisalhamento de direção E-W, com movimentação neotectônica atual, formando uma estrutura romboédrica do tipo "pull-apart. Os sismos na Bacia Sedimentar do Pantanal apresentam valores entre 0,6 a 5,4mb. Na região de cisalhamento rúptil compreendido pelo lineamento do Negro, área compreendida pelo brejão do Negro, suas magnitudes apresentam mais elevadas variando entre 3,0 e 4,0 mb. Terremotos recentes registrados na Bacia do Pantanal são resultados de uma compressão uniforme tensões na direção leste-oeste. Estes lineamentos impõem "landforms" sismo-tectônicos sendo indicados por subsidência, escarpamentos, avulsões fluviais, capturas fluviais, cotovelos, bordas retilíneas do lago dentre outros, associados à atividade neotectônica presente na Bacia Sedimentar do Pantanal. A partir dos levantamentos de descontinuidades estruturais e sismológicos identificaram dois eventos tectônicos para a área: o primeiro relacionado à uma tectônica distensiva, associada abertura da bacia e o segundo transcorrente. 